\title{
A Suitable Polysulfide Electrolyte for CdSe Quantum Dot-Sensitized Solar Cells
}

\author{
H. K. Jun, M. A. Careem, and A. K. Arof \\ Centre for Ionics University of Malaya, Department of Physics, University of Malaya, 50603 Kuala Lumpur, Malaysia
}

Correspondence should be addressed to A. K. Arof; akarof@um.edu.my

Received 22 November 2012; Revised 29 January 2013; Accepted 29 January 2013

Academic Editor: Daniel Chemisana

Copyright (C) 2013 H. K. Jun et al. This is an open access article distributed under the Creative Commons Attribution License, which permits unrestricted use, distribution, and reproduction in any medium, provided the original work is properly cited.

\begin{abstract}
A polysulfide liquid electrolyte is developed for the application in CdSe quantum dot-sensitized solar cells (QDSSCs). A solvent consisting of ethanol and water in the ratio of $8: 2$ by volume has been found as the optimum solvent for preparing the liquid electrolytes. This solvent ratio appears to give higher cell efficiency compared to pure ethanol or water as a solvent. $\mathrm{Na}_{2} \mathrm{~S}$ and $\mathrm{S}$ give rise to a good redox couple in the electrolyte for QDSSC operation, and the optimum concentrations required are $0.5 \mathrm{M}$ and $0.1 \mathrm{M}$, respectively. Addition of guanidine thiocyanate $(\mathrm{GuSCN})$ to the electrolyte further enhances the performance. The QDSSC with CdSe sensitized electrode prepared using 7 cycles of successive ionic layer adsorption and reaction (SILAR) produces an efficiency of $1.41 \%$ with a fill factor of $44 \%$ on using a polysulfide electrolyte of $0.5 \mathrm{M} \mathrm{Na}_{2} \mathrm{~S}, 0.1 \mathrm{M} \mathrm{S}$, and $0.05 \mathrm{M} \mathrm{GuSCN}$ in ethanol/water $(8: 2$ by volume) under the illumination of $100 \mathrm{~mW} / \mathrm{cm}^{2}$ white light. Inclusion of small amount of $\mathrm{TiO}_{2}$ nanoparticles into the electrolyte helps to stabilize the polysulfide electrolyte and thereby improve the stability of the CdSe QDSSC. The CdSe QDs are also found to be stable in the optimized polysulfide liquid electrolyte.
\end{abstract}

\section{Introduction}

Dye-sensitized solar cells (DSSCs) have been the focus of research in recent decade due to their low cost and ease of fabrication $[1,2]$. Recently quantum dot-sensitized solar cells (QDSSCs) are emerging as an alternative to DSSCs to overcome the stability issues of the latter. A QDSSC uses a semiconductor quantum dot (QD) as the light absorber instead of the usual inorganic dyes [3-5]. QDSSCs are being investigated as promising low-cost solar cells as they offer more advantages compared to DSSCs. Notable advantages of QDs include easy preparation, tunable band gap energy, high extinction coefficient, and multiple exciton generation [6-10]. Among the semiconductor QD choices, CdS and CdSe are the widely used QDs in QDSSCs.

For the operation of a DSSC or QDSSC, a good electrolyte with a redox mediator is required. The redox mediator regenerates the oxidized sensitizer by donating an electron. Unfortunately, there are not many electrolyte/redox mediator systems which can function in both DSSCs and QDSSCs. DSSCs work best with iodide-based electrolyte systems [11]. However, in QDSSCs, iodide-based electrolytes produce very poor results [12-15]. Nevertheless, with appropriate coating on the QDs surface, a good efficiency result can be obtained with $\mathrm{I}^{-} / \mathrm{I}_{3}{ }^{-}$redox electrolyte as shown by Shalom et al. [14]. Therefore, the electrolyte chosen has played a major role in determining the QDSSCs' performance [15]. In general, polysulfide electrolytes have been used by many researchers as an electrolyte of choice for QDSSCs [16, 17]. An optimized polysulfide electrolyte system has been reported for use in CdS QDSSCs by Lee and Chang [18]. We have used the same polysulfide electrolyte in a QDSSC based on CdSe QD prepared using 6 cycles of successive ionic layer adsorption and reaction (SILAR), and the cell showed a very low efficiency of $0.65 \%$. There are many different polysulfide compositions reported in the literature which give reasonable efficiencies for CdSe QDSSCs [16, 19-21]. The compositions reported range from pure aqueous solutions to solutions containing various amounts of $\mathrm{KCl}, \mathrm{NaOH}$, or $\mathrm{KOH}$ as additives. Lee et al. reported an efficiency of $2.9 \%$ in a CdSe QDSSC by using an electrolyte consisting of $\mathrm{Na}_{2} \mathrm{~S}, \mathrm{~S}$ and $\mathrm{KCl}$ in water/methanol mixture [16]. Meanwhile, Diguna et al. obtained an efficiency of $2.7 \%$ with just $\mathrm{Na}_{2} \mathrm{~S}$ and $\mathrm{S}$ in the liquid electrolyte [19]. However, a lower efficiency of 
$1.83 \%$ has been reported with an electrolyte composition of $\mathrm{Na}_{2} \mathrm{~S}, \mathrm{~S}$, and $\mathrm{NaOH}$ [20]. A somewhat lower efficiency was obtained by Salant et al. with an electrolyte composition of $\mathrm{Na}_{2} \mathrm{~S}, \mathrm{~S}$, and $\mathrm{KOH}$ [21]. The different conversion energy efficiencies ranging from $1.50 \%$ to about $3.00 \%$ reported by the above researchers may have arisen due to different QDSSC system involved such as variation in the electrolytes used, the way the QDs were prepared, and the surface treatment of the photoanode. The discrepancies in the results reported motivated us to undertake a systematic study to find a suitable polysulfide-based electrolyte system that can result in optimum performance in CdSe-based QDSSCs.

In this study, we have fabricated a standard CdSe QDSSC with platinum as the counter electrode. CdSe QD-sensitized electrode was prepared using SILAR method. The thickness of $\mathrm{TiO}_{2}$ layer was kept constant in all QDSSCs with no surface treatment. Various compositions of polysulfide liquid electrolyte were prepared and then tested in the QDSSCs to determine the optimum performing electrolyte. The performance of the QDSSC with the optimized polysulfide electrolyte was then evaluated over two hours to assess the stability of the cell. To the authors' best knowledge, there is no report in the literature on the optimization of polysulfide electrolyte for use in CdSe QDSSC prepared from SILAR method. Hence, the outcome of this study may lead to a basic electrolyte of the polysulfide system for application in CdSe QDSSCs.

\section{Experimental}

2.1. Materials. Titanium dioxide $\left(\mathrm{TiO}_{2}\right)$ paste $(18 \mathrm{NR})$ was purchased from JGC C\&C, Japan. Platinum catalyst solution (Plastisol) and fluorine-doped tin oxide (FTO) conducting glass ( $8 \Omega /$ sq sheet resistance) were obtained from Solaronix, Switzerland. Compact layer solution, diisopropoxy titanium bis(acetylacetonate) was procured from Sigma-Aldrich and diluted with ethanol to obtain a $0.38 \mathrm{M}$ solution. Cadmium nitrate tetrahydrate, selenium dioxide, sodium borohydride, potassium chloride, sulfur, guanidine thiocyanate (GuSCN), and $\mathrm{TiO}_{2}$ nanoparticles powder were all procured from Sigma-Aldrich, while sodium sulfide nonahydrate was obtained from Bendosen, Germany.

\subsection{Preparation of $\mathrm{TiO}_{2}$ Film Photoanodes and Counter Elec-} trodes. FTO conducting glasses were used as substrates for both working and counter electrodes. For the working electrode or photoanode, a compact layer of $\mathrm{TiO}_{2}$ was first prepared by spin coating diisopropoxy titanium bis(acetylacetonate) solution on the substrate surface. Spin coating was performed at $3000 \mathrm{rpm}$ for 10 seconds. Then the solution coated FTO glass was sintered at $450^{\circ} \mathrm{C}$ for 30 minutes. The acquired $\mathrm{TiO}_{2}$ compact layer will improve the adhesion of $\mathrm{TiO}_{2}$ to the substrate and at the same time provide a larger $\mathrm{TiO}_{2} /$ FTO contact area ratio. The compact layer also prevents the electron recombination in the solar cell by minimizing the contact between the redox electrolyte and the conductive FTO surface [22]. $\mathrm{TiO}_{2}$ paste was subsequently deposited on top of the compact layer using doctor-blade method. The newly deposited layer was sintered at $450^{\circ} \mathrm{C}$ for 30 minutes in order to remove any organic residues and moisture as well as to obtain a mesoporous $\mathrm{TiO}_{2}$ layer. The SEM image showed that mesoporous $\mathrm{TiO}_{2}$ layer has a thickness of about $5 \mu \mathrm{m}$.

Counter electrodes were prepared by spin coating a thin layer of Plastisol solution on FTO conducting surfaces. The electrodes were then sintered at $450^{\circ} \mathrm{C}$ for 30 minutes.

2.3. Fabrication of CdSe QD-Sensitized Electrodes. CdSe QDs were prepared using the SILAR deposition method. The QD synthesis process was performed in a glove box filled with argon gas following the procedure reported in the literature [23]. $\mathrm{TiO}_{2}$-coated electrode was first dipped into $0.03 \mathrm{M}$ $\mathrm{Cd}\left(\mathrm{NO}_{3}\right)_{2}$ ethanol solution for $30 \mathrm{~s}$ followed by ethanol rinsing and drying. Then the electrode was dipped into $\mathrm{Se}^{2-}$ solution for $30 \mathrm{~s}$ followed by ethanol rinsing and drying. $\mathrm{Se}^{2-}$ solution was prepared by reacting $0.03 \mathrm{M} \mathrm{SeO}_{2}$ ethanolic solution with $0.06 \mathrm{M} \mathrm{NaBH}_{4}$. The mixture was stirred for about an hour before it was used for SILAR dipping process. This two-step dipping process is termed as 1 SILAR cycle. All QDs used were deposited using 7 SILAR cycles (based on optimization study performed by the author).

2.4. Assembly of QDSSCs. A sandwich-type cell was fabricated by clamping the working electrode with the counter electrode. Parafilm (130 $\mu \mathrm{m}$ thickness) was used as a spacer. A droplet of the electrolyte was dropped onto the surface of QDsensitized $\mathrm{TiO}_{2}$ film prior to cell assembly. The procedure was repeated until the $\mathrm{QD}$-sensitized $\mathrm{TiO}_{2}$ film was covered with the electrolyte. The effective working area used was $0.25 \mathrm{~cm}^{2}$. This assembly method is slightly different from the common method where Surlyn tape is used as spacer with proper sealing. In our case, careful attention was given to ensure that the electrolyte has covered the aperture of the parafilm spacer before the cell assembly. There was no external sealing applied as the parafilm spacer was adequate to prevent the electrolyte from leaking. Polysulfide electrolyte solution was prepared from $\mathrm{Na}_{2} \mathrm{~S}, \mathrm{~S}, \mathrm{KCl}, \mathrm{GuSCN}$, and $\mathrm{TiO}_{2}$ in waterethanol mixture. The concentration of each material in the electrolyte is given in detail in Section 3.

2.5. Photoresponse Measurements. Photocurrent-voltage (I$V)$ characteristics of the QDSSCs were measured using a Keithley 2400 electrometer under illumination from a xenon lamp at the intensity of $100 \mathrm{~mW} / \mathrm{cm}^{2}$. Efficiency was calculated from

$$
\eta=\frac{J_{\mathrm{SC}} \times V_{\mathrm{OC}} \times \mathrm{FF}}{P_{\text {in }}},
$$

where $J_{\mathrm{SC}}$ is photocurrent density measured at short-circuit, $V_{\mathrm{OC}}$ is open-circuit voltage, $\mathrm{FF}$ is fill factor, and $P_{\text {in }}$ is the intensity of the incident light. Measurement on each cell was repeated three times to ensure the consistency of the data. In order to confirm the best performance, measurements were repeated on another identical cell, and reproducibility of the results was checked.

\section{Results and Discussion}

3.1. Determining the Optimum Solvent for the Electrolyte. Most of the polysulfide electrolytes were prepared as aqueous 


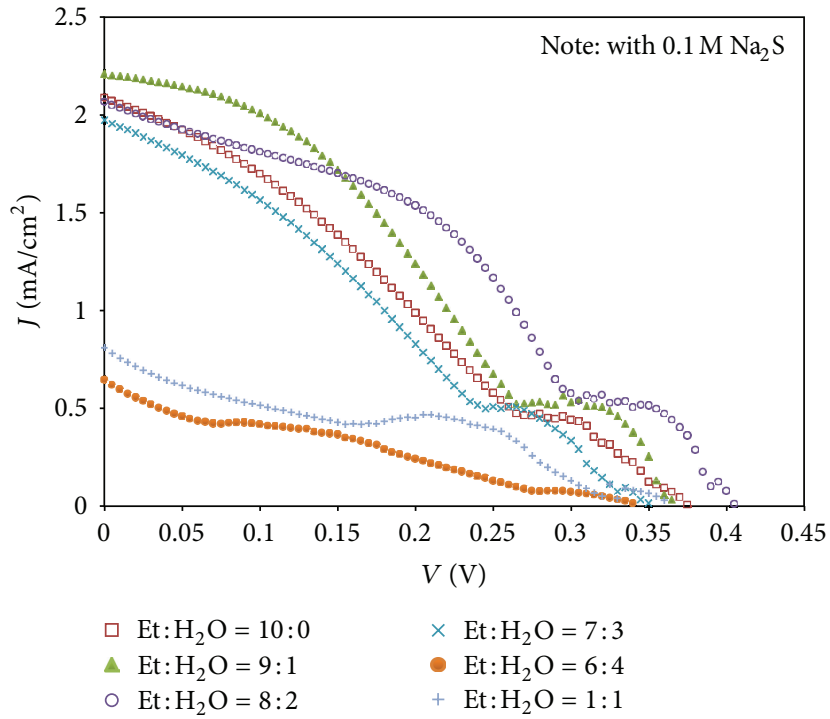

(a)

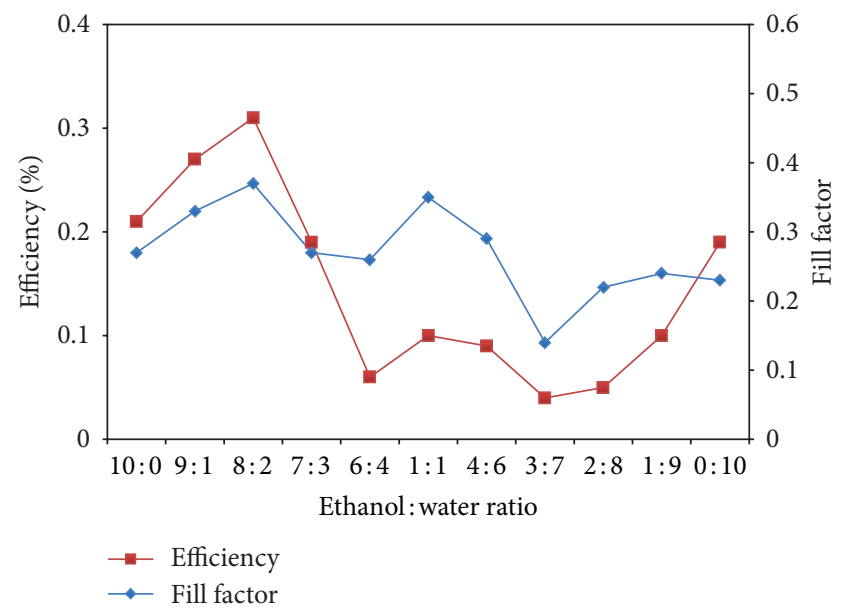

(b)

FIgURE 1: (a) $J-V$ curves of CdSe QDSSCs with $0.1 \mathrm{M} \mathrm{Na}_{2}$ S electrolyte having various solvent ratio. (b) Variation of efficiency and fill factor of the cells with different solvent ratio in the electrolyte.

TABLE 1: Performance parameters of CdSe QDSSCs with $0.1 \mathrm{M} \mathrm{Na}_{2} \mathrm{~S}$ electrolytes having various solvent ratio.

\begin{tabular}{|c|c|c|c|c|}
\hline Solution composition of the electrolyte & $J_{\mathrm{SC}}\left(\mathrm{mA} / \mathrm{cm}^{2}\right)$ & $V_{\mathrm{OC}}(\mathrm{V})$ & Fill factor (\%) & Efficiency, $\eta(\%)$ \\
\hline Methanol 100\% & 0.42 & 0.305 & 16.0 & 0.02 \\
\hline Ethanol 100\% & 2.09 & 0.375 & 27.0 & 0.21 \\
\hline Ethanol: water $=9: 1$ & 2.21 & 0.365 & 33.0 & 0.27 \\
\hline Ethanol: water $=8: 2$ & 2.07 & 0.405 & 37.0 & 0.31 \\
\hline Ethanol: water $=7: 3$ & 1.97 & 0.350 & 27.0 & 0.19 \\
\hline Ethanol: water $=6: 4$ & 0.65 & 0.340 & 26.0 & 0.06 \\
\hline Ethanol: water $=1: 1$ & 0.81 & 0.360 & 35.0 & 0.10 \\
\hline Ethanol: water $=4: 6$ & 0.85 & 0.345 & 29.0 & 0.09 \\
\hline Ethanol: water $=3: 7$ & 0.82 & 0.340 & 14.0 & 0.04 \\
\hline Ethanol: water $=2: 8$ & 0.62 & 0.360 & 22.0 & 0.05 \\
\hline Ethanol: water $=1: 9$ & 1.21 & 0.340 & 24.0 & 0.10 \\
\hline Water $100 \%$ & 2.09 & 0.395 & 23.0 & 0.19 \\
\hline
\end{tabular}

solutions. However, recently Lee and Chang proposed to mix methanol with water for the electrolyte preparation [18]. The use of alcohol was suggested to reduce the high surface tension of the aqueous solution. High surface tension will result in a low penetration and poor wetting of the solution in the mesoporous $\mathrm{TiO}_{2}$ film. To overcome this problem, alcohol (methanol or ethanol) solution is used as cosolvent for the electrolyte solution.

We start with the comparison of pure alcohol and aqueous solution as a solvent for the electrolyte. Appropriate amount of $\mathrm{Na}_{2} \mathrm{~S}$ only was used to prepare the $0.1 \mathrm{M}$ electrolyte solution. Figure 1(a) shows the $J-V$ curves of QDSSCs fabricated with electrolytes having selected ratio of cosolvents, and Figure 1(b) shows the variation of efficiencies and fill factors of all cells investigated with the ethanol/water ratio in the electrolyte. Table 1 shows the summary of the performance parameters of all cells investigated, which were prepared with electrolytes having different ratio of cosolvents.
With the pure water aqueous electrolyte solution (water $100 \%$ ), the efficiency of the QDSSC is found to be $0.19 \%$ with a short-circuit photocurrent density of $2.09 \mathrm{~mA} / \mathrm{cm}^{2}$. However, with pure methanol electrolyte solution (methanol 100\%), the solar cell does not perform well. The efficiency is only $0.02 \%$ with a short-circuit photocurrent density of $0.2 \mathrm{~mA} / \mathrm{cm}^{2}$. Both solutions produce an open-circuit voltage above $0.3 \mathrm{~V}$. Fill factor is rather low, that is, $23 \%$ for the water solution and $16 \%$ for the methanol solution. With another alcoholbased solution, pure ethanol solution (ethanol 100\%), a cell efficiency of $0.21 \%$ with a short-circuit photocurrent density of $2.09 \mathrm{~mA} / \mathrm{cm}^{2}$ is observed. Ethanol seems to be a better solvent compared with methanol as it yields a better fill factor value of $27 \%$. Ethanol has a surface tension of $21.82 \mathrm{mN} / \mathrm{m}$ at room temperature compared with $22.51 \mathrm{mN} / \mathrm{m}$ of methanol [24]. However, surface tension is only part of the contributing factors for the solar cell performance. The ethanol can also serve as a sacrificial hole scavenger that allows easy hole 


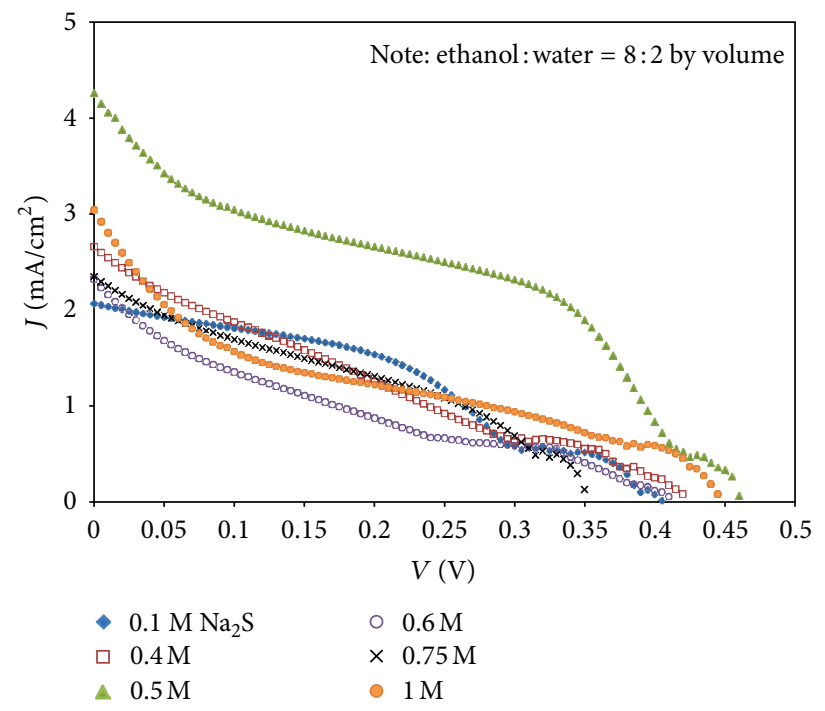

(a)

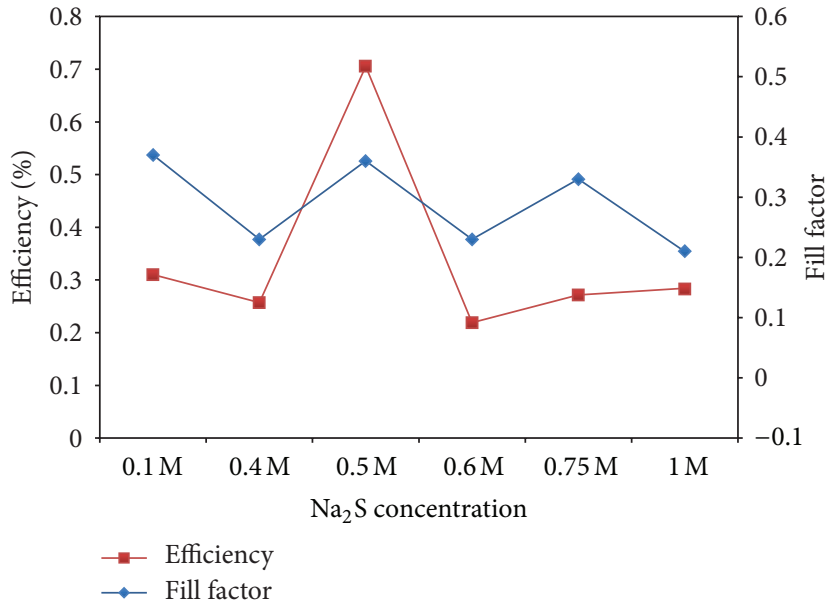

(b)

FIGURE 2: (a) $J-V$ curves of CdSe QDSSCs with electrolytes having various amounts of $\mathrm{Na}_{2} \mathrm{~S}$. (b) Variation of efficiency and fill factor of the cells with the amount of $\mathrm{Na}_{2} \mathrm{~S}$ in the electrolyte.

transfer from the excited CdSe QDs and prevents the recombination of the charge carriers [25]. Therefore, a mixture of water and ethanol is chosen as the solvent in our subsequent investigations. The ratio of ethanol and water is varied to prepare the co-solvent solution for the electrolyte.

From the results, we can see that the best cell performance is obtained when the solution consists of ethanol/water ratio of $8 / 2$ (by volume). The cell with this electrolyte has the best efficiency of $0.31 \%$ with a short-circuit photocurrent density of $2.07 \mathrm{~mA} / \mathrm{cm}^{2}$. This result is better than the results obtained for cells with single solvent-based electrolytes. This cell also has the highest fill factor (37\%) among the cells prepared with other electrolyte solutions. As the ratio of the ethanol part in the electrolyte solution decreases, efficiency of the cell is found to decrease. It is clear that electrolytes having ratio of ethanol to water greater than 7 give better performance. This indicates the importance of ethanol in making the electrolyte penetrate deep into the mesoporous $\mathrm{TiO}_{2}$ film and wet the pores. The penetration and wetting depends on the combination of viscosity and surface tension of the electrolyte solution. As the maximum performance is obtained with the electrolyte having ethanol/water ratio of $8 / 2$, this composition is used for further studies to enhance the performance of the QDSSCs. It is interesting to note that QDSSCs work without $\mathrm{S}$ in the $\mathrm{Na}_{2} \mathrm{~S}$ electrolyte, but the $J-V$ curves of the cell appear to be different in that the curves level off at higher applied voltage in the range $0.25-0.35 \mathrm{~V}$ before eventually dropping to zero photocurrent density. We attribute this effect to the absence of regenerative species of $\mathrm{S}_{x}{ }^{2-}$ in the electrolyte and the hole scavenging effect from alcohol which results in nonregenerative cells [25-27]. The use of alcohol in the solar cell electrolyte will lead to alcohol oxidation at the photoanode and at the same time it itself is a sacrificial donor by scavenging photogenerated holes. It is therefore of great importance to further optimize the $\mathrm{Na}_{2} \mathrm{~S}$ concentration as well as the inclusion of regenerative species $S_{x}{ }^{2-}$ in the optimized solvent of ethanol/water (8/2 by volume). Further investigations are necessary to understand the exact reasons for the unusual shape of the $J-V$ curves when $\mathrm{S}$ is absent in the electrolytes.

3.2. Determining the Optimum $\mathrm{Na}_{2} \mathrm{~S}$ Salt Concentration for the Electrolyte. As the efficiency of the cell obtained with $0.1 \mathrm{M} \mathrm{Na}_{2} \mathrm{~S}$ electrolyte is low, it is imperative to optimize the $\mathrm{Na}_{2} \mathrm{~S}$ concentration in the electrolyte solution. The amount of $\mathrm{Na}_{2} \mathrm{~S}$ is varied in the solution having ethanol/water: $8 / 2$ (by volume) to obtain electrolyte solutions of different concentrations ranging from 0.1 to $1.0 \mathrm{M}$. The corresponding $J-V$ curves of the cells having different concentration of $\mathrm{Na}_{2} \mathrm{~S}$ are shown in Figure 2(a), while the variation of the efficiencies and fill factors with the concentrations are shown Figure 2(b). Table 2 summarizes the performance parameters of the cells prepared with electrolytes having different concentration of $\mathrm{Na}_{2} \mathrm{~S}$. From the results, optimum performance is obtained for the cells with an electrolyte having $0.5 \mathrm{M}$ of $\mathrm{Na}_{2} \mathrm{~S}$. This cell has an efficiency of $0.71 \%$ with an improved short-circuit photocurrent density of $4.26 \mathrm{~mA} / \mathrm{cm}^{2}$ as well as a better open-circuit voltage of $0.46 \mathrm{~V}$. However, there is not much change in the fill factor value.

Further increase of $\mathrm{Na}_{2} \mathrm{~S}$ in the electrolyte solution above $0.5 \mathrm{M}$ does not improve the cell performance. It should be noted that $\mathrm{Na}_{2} \mathrm{~S}$ is only slightly soluble in alcohol but well soluble in water. As such, higher concentration of salt may not incur full solubility in the co-solvent. The results obtained suggest that for the best performance of the QDSSC the electrolyte must have an optimum $\mathrm{Na}_{2} \mathrm{~S}$ concentration of $0.5 \mathrm{M}$. With higher salt concentration, charge recombination at the photo electrode and electrolyte interface is enhanced as evidenced by the low fill factor value. This also implies a slow 
TABLE 2: Performance parameters of CdSe QDSSCs with electrolytes having various amounts of $\mathrm{Na}_{2} \mathrm{~S}$ in ethanol/water ( $8: 2$ by volume) solution.

\begin{tabular}{lcccc}
\hline $\mathrm{Na}_{2} \mathrm{~S}$ concentration in the electrolyte & $J_{\mathrm{SC}}\left(\mathrm{mA} / \mathrm{cm}^{2}\right)$ & $V_{\mathrm{OC}}(\mathrm{V})$ & Fill factor $(\%)$ & 37.0 \\
\hline $0.1 \mathrm{M}$ & 2.07 & 0.405 & 23.0 & 0.31 \\
$0.4 \mathrm{M}$ & 2.66 & 0.420 & 36.0 & 0.26 \\
$0.5 \mathrm{M}$ & 4.26 & 0.460 & 23.0 & 0.71 \\
$0.6 \mathrm{M}$ & 2.32 & 0.410 & 33.0 & 0.22 \\
$0.75 \mathrm{M}$ & 2.35 & 0.350 & 21.0 & 0.27 \\
$1.0 \mathrm{M}$ & 3.04 & 0.445 & 0.28 \\
\hline
\end{tabular}

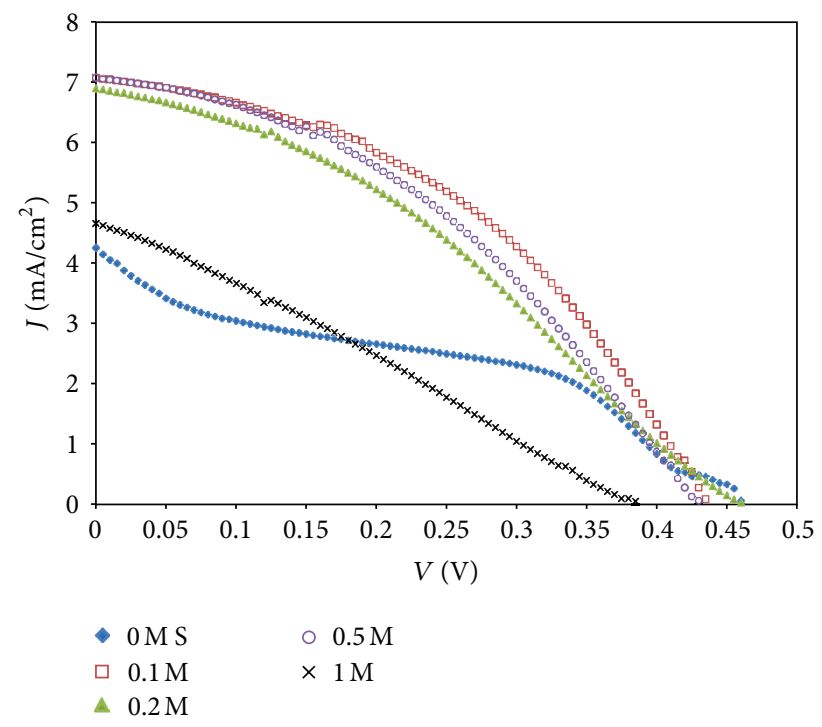

(a)

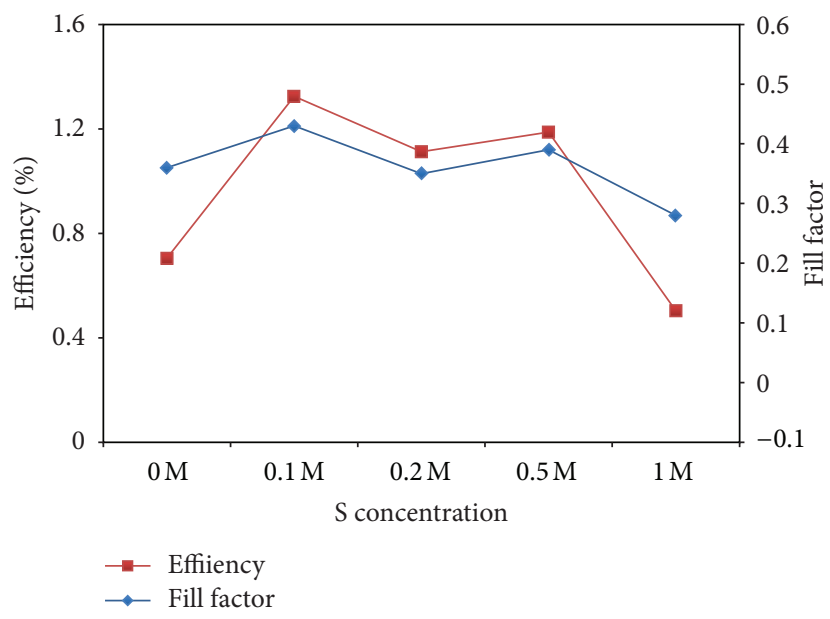

(b)

Figure 3: (a) $J-V$ curves of CdSe QDSSCs with electrolytes having various amount of S. (b) Variation of efficiency and fill factor of the cells with the amount of $S$ in the electrolyte. The electrolyte used: $0.5 \mathrm{M} \mathrm{Na}_{2} \mathrm{~S}$ in ethanol/water ( $8: 2$ by volume).

hole recovery rate from the oxidized QD by the high concentration electrolytes. It is interesting to note that the QDSSC works with only $\mathrm{Na}_{2} \mathrm{~S}$ in the electrolyte, but the $J-V$ curves have somewhat irregular shapes (Figure 1(b)). The absence of regenerative $S$ species in the electrolyte may have resulted in these irregular shapes as indicated in Section 3.1. This problem can be mitigated by the addition of sulfur to form the polysulfide redox couple (see Section 3.3). It should be noted that without the sulfur in the electrolyte the QDCCs will not function continuously.

3.3. Determining the Sulfur Content Needed for the Best Performance of the Cells. In order to obtain a regenerative redox couple, a second element is needed to couple with $\mathrm{S}^{2-}$ from the $\mathrm{Na}_{2} \mathrm{~S}$. In most studies, sulfur is added to the sulfide salt to form a polysulfide $\left(S^{2-} / S_{x}{ }^{2-}\right)$ redox couple. From the perspective of chemical reaction, oxidation occurs at the photoanode-electrolyte interface according to [28]

$$
\begin{gathered}
\mathrm{S}^{2-}+2 \mathrm{~h}^{+} \longrightarrow \mathrm{S}, \\
\mathrm{S}+\mathrm{S}_{x-1}{ }^{2-} \longrightarrow \mathrm{S}_{x}^{2-} \quad(x=2-5) .
\end{gathered}
$$

At the counter electrode, reduction occurs where $S_{x}{ }^{2-}$ is reverted back to $\mathrm{S}^{2-}$ :

$$
\mathrm{S}_{x}{ }^{2-}+2 \mathrm{e}^{-} \longrightarrow \mathrm{S}_{x-1}{ }^{2-}+\mathrm{S}^{2-} \text {. }
$$

This chemical reaction is thought to enhance the hole recovery rate which results in a higher performance of solar cell [29]. Ardoin and Winnick suggested that the active species at the photoanode would be the disulfide ion [30].

In this study, we have added sulfur into the $0.5 \mathrm{M} \mathrm{Na}_{2} \mathrm{~S}$ solution. The amount of the sulfur added is varied, and the efficiency of the cell utilizing each electrolyte is obtained. Due to limited solubility of sulfur in alcohol, the amount of the sulfur added is limited to $1.0 \mathrm{M}$. The performance trend along with $J-V$ curves of cells having different amount of $S$ are shown in Figure 3, and the performance parameters of the cells are summarized in Table 3. The results show that addition of $0.1 \mathrm{M}$ of sulfur to the electrolyte enhances the cell efficiency to a best value of $1.32 \%$ and produces the best fill factor of $43 \%$. Photocurrent density is also improved to a higher value of $7.08 \mathrm{~mA} / \mathrm{cm}^{2}$. The overall efficiency has more than $80 \%$ improvement which is largely attributed to the enhancement of photocurrent density. This shows that 


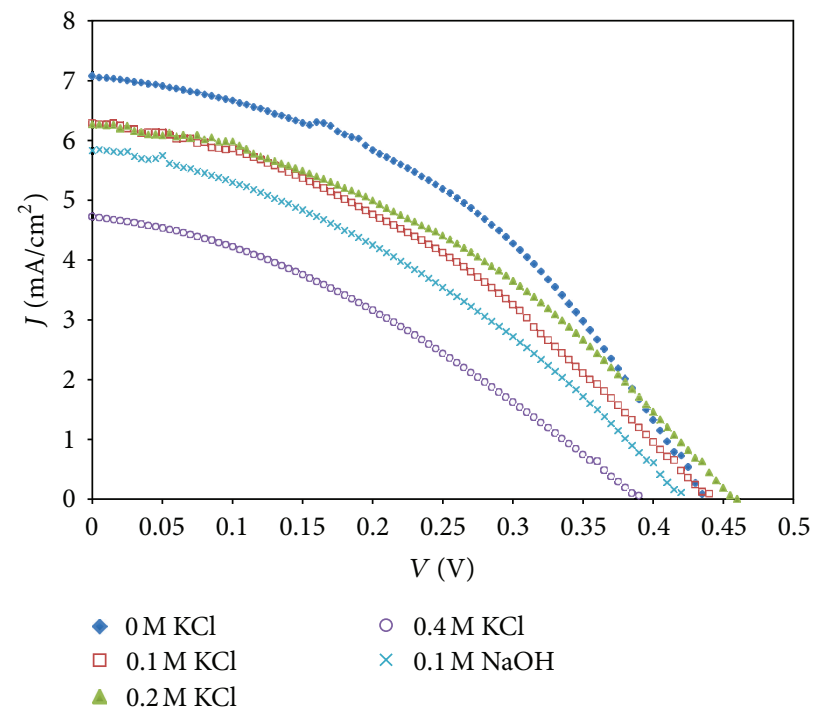

(a)

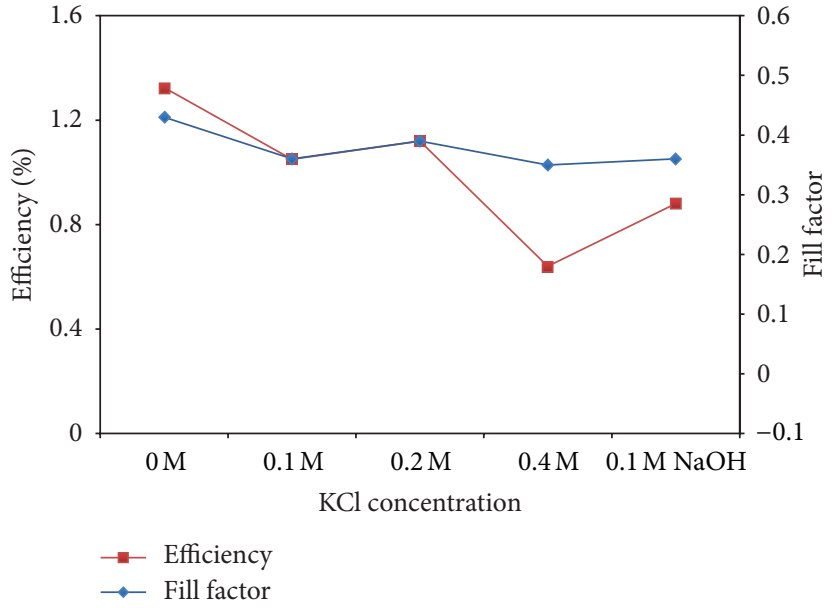

(b)

FIGURE 4: (a) $J-V$ curves of CdSe QDSSCs with electrolytes having various amounts of KCl addtive. (b) Variation of efficiency and fill factor of the cells with the amount of $\mathrm{KCl}$ in the electrolyte. Electrolyte used: $0.5 \mathrm{M} \mathrm{Na}_{2} \mathrm{~S}, 0.1 \mathrm{M} \mathrm{S}$ in ethanol/water ( $8: 2$ by volume).

TABLE 3: Performance parameters of CdSe QDSSCs with electrolytes having various amounts of S. The electrolyte used: $0.5 \mathrm{M} \mathrm{Na}_{2} \mathrm{~S}$ in ethanol/water ( $8: 2$ by volume).

\begin{tabular}{|c|c|c|c|c|}
\hline S concentration in the electrolyte & $J_{\mathrm{SC}}\left(\mathrm{mA} / \mathrm{cm}^{2}\right)$ & $V_{\mathrm{OC}}(\mathrm{V})$ & Fill factor (\%) & Efficiency, $\eta(\%)$ \\
\hline $0 \mathrm{M}$ & 4.26 & 0.460 & 36.0 & 0.71 \\
\hline $0.1 \mathrm{M}$ & 7.08 & 0.435 & 43.0 & 1.32 \\
\hline $0.2 \mathrm{M}$ & 6.91 & 0.460 & 35.0 & 1.11 \\
\hline $0.5 \mathrm{M}$ & 7.08 & 0.430 & 39.0 & 1.19 \\
\hline $1.0 \mathrm{M}$ & 4.66 & 0.385 & 28.0 & 0.50 \\
\hline
\end{tabular}

addition of sulfur in small amount up to $0.1 \mathrm{M}$ concentration increases the cell performance. However, further increase of sulfur amount does not yield better performance. We attribute this to the solubility limit of sulfur in the solvent. Note that with the addition of sulfur in the electrolyte, the $J-V$ curves take the regular shapes.

\subsection{Determining Additives Needed in the Electrolyte for the} Optimum Performance of Cells. The introduction of additives to the electrolyte has been shown to enhance the photocurrent generated and thereby improve the performance of QDSSCs [18, 31]. Lee and Chang have added $\mathrm{KCl}$ to the electrolyte to further enhance the performance of $\mathrm{CdS}$ QDSSCs [18]. The presence of $\mathrm{KCl}$ increased the performance of the cell as well as the electrolyte solution conductivity. In the present study, we have added different amounts of $\mathrm{KCl}$ to the optimized $0.5 \mathrm{M} \mathrm{Na}_{2} \mathrm{~S}$ and $0.1 \mathrm{M} \mathrm{S}$ solution. However, we noticed that the performance of the cells did not improve. The electrolyte without $\mathrm{KCl}$ appears to be superior in our case (see Figure 4(a)). Addition of $\mathrm{KCl}$ actually decreased the photocurrent density in contradiction to Lee and Chang's work. The difference may be due to different solvent mixtures as they have used a mixture of methanol and water as cosolvent. The presence of anion $\mathrm{Cl}^{-}$in the electrolyte may have altered the CdSe QDs surface which could have resulted in a lower cell performance. At present, the mechanism of the $\mathrm{Cl}^{-}$ effect is not well understood.

Replacement of $\mathrm{KCl}$ with $\mathrm{NaOH}$ also did not produce any improvement either in the performance of QDSSCs (see Figure 4(a)). This is expected as $\mathrm{KCl}$ is more electropositive than $\mathrm{NaOH}$. Thus the conductivity of the electrolyte with added $\mathrm{NaOH}$ should be lower compared with that of the electrolyte with added $\mathrm{KCl}$. The performance parameters of $\mathrm{CdSe}$-sensitized solar cells with electrolytes having $\mathrm{KCl}$ or $\mathrm{NaOH}$ additive are summarized in Table 4. Figure 4(a) shows the corresponding $J-V$ curves, and the trend of the variation of parameters with $\mathrm{KCl}$ additive is shown in Figure 4(b).

In a DSSC work reported by Zhang et al., guanidine thiocyanate (GuSCN) was added to the $\mathrm{I}^{-} / \mathrm{I}_{3}{ }^{-}$electrolyte system for the improvement of performance and stability [32]. Following this report, Chou et al. have tried GuSCN additive in CdS QDSSC and obtained enhancement in current density and efficiency [31]. In order to try this additive to the CdSe QDSSC, we have added different amounts of GuSCN into our optimized electrolyte solution having $0.5 \mathrm{M} \mathrm{Na} \mathrm{N}_{2}$ and $0.1 \mathrm{M} \mathrm{S}$ in ethanol/water ( $8 / 2$ by volume). The presence of GuSCN decreases the photocurrent density but increases the open-circuit voltage in contrast to the significant improvement in photocurrent density reported by Chou et al. [31]. This difference 
TABLE 4: Performance parameters of CdSe QDSSCs with electrolytes having various amounts of $\mathrm{KCl}$ additive. Electrolyte used: $0.5 \mathrm{M} \mathrm{Na}_{2} \mathrm{~S}$, $0.1 \mathrm{M} \mathrm{S}$ in ethanol/water $(8: 2$ by volume).

\begin{tabular}{lcccc}
\hline $\mathrm{KCl}$ concentration in the electrolyte & $J_{\mathrm{SC}}\left(\mathrm{mA} / \mathrm{cm}^{2}\right)$ & $V_{\mathrm{OC}}(\mathrm{V})$ & Fill factor $(\%)$ & 43.0 \\
\hline $0 \mathrm{M}$ & 7.08 & 0.435 & 36.0 & 1.32 \\
$0.1 \mathrm{M}$ & 6.60 & 0.440 & 39.0 & 1.05 \\
$0.2 \mathrm{M}$ & 6.27 & 0.460 & 35.0 & 1.12 \\
$0.4 \mathrm{M}$ & 4.22 & 0.390 & 36.0 & 0.64 \\
$0.1 \mathrm{M} \mathrm{NaOH}$ & 5.83 & 0.420 & & 0.88 \\
\hline
\end{tabular}

TABLE 5: Performance parameters of CdSe QDSSC with electrolytes having various amounts of GuSCN additive. Electrolyte used: $0.5 \mathrm{M} \mathrm{Na}_{2} \mathrm{~S}$, $0.1 \mathrm{M} \mathrm{S}$ in ethanol/water ( $8: 2$ by volume).

\begin{tabular}{lcccc}
\hline GuSCN concentration in the electrolyte & $J_{\mathrm{SC}}\left(\mathrm{mA} / \mathrm{cm}^{2}\right)$ & $V_{\mathrm{OC}}(\mathrm{V})$ & Fill factor $(\%)$ & 43.0 \\
\hline $0 \mathrm{M}$ & 7.08 & 0.435 & 44.0 & 1.32 \\
$0.05 \mathrm{M}$ & 6.80 & 0.470 & 37.0 & 1.41 \\
$0.1 \mathrm{M}$ & 6.98 & 0.455 & 42.0 & 1.18 \\
$0.2 \mathrm{M}$ & 6.95 & 0.445 & 1.30 \\
\hline
\end{tabular}

could be attributed to the different electrolyte compositions and QD-sensitized photoanodes involved. Only a small amount of GuSCN is required to enhance our polysulfide electrolyte. In our case, $0.05 \mathrm{M}$ of GuSCN can boost the cell performance to a best efficiency of $1.41 \%$ with the best fill factor of $44 \%$ and the best open-circuit voltage of $0.470 \mathrm{~V}$ (see Table 5). The performance parameters of the cells with electrolytes having various amounts of GuSCN are summarized in Table 5, and the $J-V$ curves of the cells and performance trend are shown in Figures 5(a) and 5(b). It should be noted that the addition of GuSCN does not result in a distinct improvement on the cell performance. An initial increase of GuSCN concentration produces a slight improvement on the cell performance as the additive assists in decreasing the interfacial recombination at the photoanode by patching up the $\mathrm{TiO}_{2}$ surface not covered by the QDs [32]. However, at higher concentration of GuSCN, cyanide may have adsorbed strongly on the CdSe QDs surface. This phenomenon may have negative effect on the electrolyte regenerative cycle, though the precise mechanism may need to be further investigated [33].

So far, we are able to reproduce the performance of the optimized electrolyte by using few similar cell assemblies with performance variance of $\pm 0.05 \%$. Our optimized polysulfide electrolyte composition is different from that of Lee and Chang as they have obtained an optimized polysulfide electrolyte consisting of $0.5 \mathrm{M} \mathrm{Na}_{2} \mathrm{~S}, 2 \mathrm{M} \mathrm{S}$, and $0.2 \mathrm{M} \mathrm{KCl}$ in methanol/water (7:3 by volume) solution [18]. It should be noted that their electrolyte is efficient in CdS QDSSCs. When the same electrolyte was applied in CdSe QDSSC (as in our study), the efficiency did not match with what has been reported. Clearly both electrolytes are sensitive to the material type involved. It is also noted that the efficiency obtained in this study for CdSe QDSSCs is lower compared to the values reported in the recent literatures where efficiency of more than $2.0 \%$ was obtained [34-36]. Table 6 lists the performance parameters of some CdSe QDSSCs from other groups for comparison. Beside different polysulfide electrolyte composition, the performance differences are largely due to different photoanode configuration, surface treatment, QD deposition method, and type of counter electrode. We acknowledge our best result is lower as our photoanode has not been fully optimized. We anticipate a better result if all the photoanode parameters are optimized (i.e., $\mathrm{TiO}_{2}$ film thickness, $\mathrm{ZnS}$ passive layer, scattering layer, and volume and size of QD deposited). The choice of counter electrode also plays an important role in the cell performance. Commonly used platinum electrode may not be suitable with polysulfide electrolyte as the S compound will adsorb on the surface affecting the electrode performance [37]. The alternative will be $\mathrm{Cu}_{2} \mathrm{~S}$ electrode which has better catalytic activity for the reduction of $\mathrm{S}_{x}{ }^{2-}$ species $[20,35]$.

3.5. Stability of the Electrolyte and the QDSSC. From our study as discussed in previous sections, the optimum polysulfide electrolyte for CdSe QDSSC consists of $0.5 \mathrm{M} \mathrm{Na}{ }_{2} \mathrm{~S}$, $0.1 \mathrm{M} \mathrm{S}$, and $0.05 \mathrm{M} \mathrm{GuSCN}$ in ethanol/water solution $(8 / 2$ by volume). To improve the stability of the electrolyte, we have added $1 \mathrm{wt} \%$ of $\mathrm{TiO}_{2}$ nanoparticles $(<400 \mathrm{~nm})$ into the solution. $\mathrm{TiO}_{2}$ is usually used as a filler in the preparation of stable high conducting polymer electrolytes. We have investigated the performance of CdSe QDSSCs having electrolytes with and without $\mathrm{TiO}_{2}$ nanoparticles under continuous soaking of light for two hours with a light intensity of $100 \mathrm{~mW} / \mathrm{cm}^{2}$. Initially the cell with the electrolyte having added $\mathrm{TiO}_{2}$ shows an efficiency of $1.39 \%$ which is slightly lower than that of the cell without $\mathrm{TiO}_{2}$ added (refer Table 7). Nevertheless, it has an improved photocurrent density of $7.70 \mathrm{~mA} / \mathrm{cm}^{2}$. When the illumination is continued, the efficiencies of both cells decrease with time. The efficiency of the cell using polysulfide electrolyte without added $\mathrm{TiO}_{2}$ appears to decrease at a faster rate compared to that of the cell using electrolyte with added $\mathrm{TiO}_{2}$. After two hours, the former reaches an efficiency of $0.72 \%$, a decrease of about $50 \%$ from initial value. For the cell using polysulfide electrolyte with added $\mathrm{TiO}_{2}$, the efficiency obtained after two hours of continuous light soaking is $1.02 \%$. 
TABLE 6: Performance parameters of CdSe QDSSC with different polysulfide electrolyte compositions reported by various groups.

\begin{tabular}{|c|c|c|c|c|c|c|}
\hline $\begin{array}{l}\text { Photoanode } \\
\text { configuration }\end{array}$ & Electrolyte composition & $\begin{array}{c}J_{\mathrm{SC}} \\
\left(\mathrm{mA} / \mathrm{cm}^{2}\right)\end{array}$ & $V_{\mathrm{OC}}(\mathrm{V})$ & $\begin{array}{l}\text { Fill factor } \\
(\%)\end{array}$ & $\begin{array}{l}\text { Efficiency } \\
\eta(\%)\end{array}$ & Reference \\
\hline $\mathrm{TiO}_{2} / \mathrm{CdSe}$ & $\begin{array}{l}0.5 \mathrm{M} \mathrm{Na}_{2} \mathrm{~S}, 0.1 \mathrm{M} \mathrm{S}, 0.05 \mathrm{M} \\
\text { GuSCN in ethanol/water } \\
\text { (8:2 by volume) }\end{array}$ & 6.80 & 0.470 & 44.0 & 1.41 & This work \\
\hline $\mathrm{TiO}_{2} / \mathrm{CdSe}$ & $\begin{array}{l}0.5 \mathrm{M} \mathrm{Na}_{2} \mathrm{~S}, 0.1 \mathrm{M} \mathrm{S}, 0.2 \mathrm{M} \\
\mathrm{KCl} \text { in methanol/water } \\
\text { ( } 3: 7 \text { by volume) }\end{array}$ & 10.61 & 0.378 & 36.0 & 1.40 & {$[16]$} \\
\hline $\mathrm{TiO}_{2} / \mathrm{CdS} / \mathrm{CdSe} / \mathrm{ZnS}$ & $\begin{array}{l}0.5 \mathrm{M} \mathrm{Na}_{2} \mathrm{~S}, 0.1 \mathrm{M} \mathrm{S}, 0.2 \mathrm{M} \\
\mathrm{KCl} \text { in methanol/water } \\
\text { ( } 3: 7 \text { by volume) }\end{array}$ & 11.66 & 0.503 & 49.0 & 2.90 & {$[16]$} \\
\hline $\mathrm{TiO}_{2} / \mathrm{CdSe}$ & $1 \mathrm{M} \mathrm{Na}_{2} \mathrm{~S}, 1 \mathrm{M} \mathrm{S}$ in aqueous & 6.03 & 0.680 & 39.0 & 1.60 & {$[19]$} \\
\hline $\mathrm{TiO}_{2} / \mathrm{F} / \mathrm{CdSe} / \mathrm{F} / \mathrm{ZnS}$ & $1 \mathrm{M} \mathrm{Na}_{2} \mathrm{~S}, 1 \mathrm{M} \mathrm{S}$ in aqueous & 7.51 & 0.710 & 50.0 & 2.70 & {$[19]$} \\
\hline $\mathrm{TiO}_{2} / \mathrm{CdSe}$ & $\begin{array}{l}1 \mathrm{M} \mathrm{Na}_{2} \mathrm{~S}, 0.1 \mathrm{M} \mathrm{S}, 0.1 \mathrm{M} \\
\mathrm{NaOH} \text { in ultrapure water }\end{array}$ & 3.06 & 0.430 & 21.0 & 0.28 & {$[20]$} \\
\hline $\mathrm{TiO}_{2} / \mathrm{CdSe} / \mathrm{ZnS}$ & $\begin{array}{l}1 \mathrm{M} \mathrm{Na}_{2} \mathrm{~S}, 0.1 \mathrm{M} \mathrm{S}, 0.1 \mathrm{M} \\
\mathrm{NaOH} \text { in ultrapure water }\end{array}$ & 7.13 & 0.510 & 48.0 & 1.83 & {$[20]$} \\
\hline $\mathrm{TiO}_{2} / \mathrm{CdSe}$ & $\begin{array}{l}1 \mathrm{M} \mathrm{Na}_{2} \mathrm{~S}, 0.1 \mathrm{M} \mathrm{S}, 0.1 \mathrm{M} \\
\mathrm{KOH} \text { in aqueous }\end{array}$ & 2.70 & 0.554 & 26.0 & 0.40 & {$[21]$} \\
\hline $\mathrm{TiO}_{2} / \mathrm{CdSe} / \mathrm{ZnS}$ & $\begin{array}{l}1 \mathrm{M} \mathrm{Na}_{2} \mathrm{~S}, 0.1 \mathrm{M} \mathrm{S}, 0.1 \mathrm{M} \\
\mathrm{KOH} \text { in aqueous }\end{array}$ & 9.00 & 0.554 & 35.0 & 1.70 & {$[21]$} \\
\hline
\end{tabular}

TABLE 7: Performance parameters of CdSe QDSSCs with and without $\mathrm{TiO}_{2}$ nanoparticles in the electrolyte. Electrolyte used: $0.5 \mathrm{M} \mathrm{Na} 2 \mathrm{~S}$, $0.1 \mathrm{M} \mathrm{S}, 0.05 \mathrm{M}$ GuSCN in ethanol/water ( $8: 2$ by volume).

\begin{tabular}{lccccc}
\hline Composition & Time $(\mathrm{min})$ & $J_{\mathrm{SC}}\left(\mathrm{mA} / \mathrm{cm}^{2}\right)$ & $V_{\mathrm{OC}}(\mathrm{V})$ & Fill factor $(\%)$ & Efficiency, $\eta(\%)$ \\
\hline \multirow{2}{*}{$0.5 \mathrm{M} \mathrm{Na}_{2} \mathrm{~S}+0.1 \mathrm{M} \mathrm{S}+0.05 \mathrm{M} \mathrm{GuSCN}$} & 0 & 6.80 & 0.470 & 44.0 & 1.41 \\
& 120 & 4.36 & 0.40 & 41.0 & 0.72 \\
\hline \multirow{2}{*}{$0.5 \mathrm{M} \mathrm{Na}_{2} \mathrm{~S}+0.1 \mathrm{M} \mathrm{S}+0.05 \mathrm{M} \mathrm{GuSCN}+1 \mathrm{wt} \% \mathrm{TiO}_{2}$} & 0 & 7.70 & 0.475 & 38.0 & 1.39 \\
& 120 & 5.27 & 0.430 & 45.0 & 1.02 \\
\hline
\end{tabular}

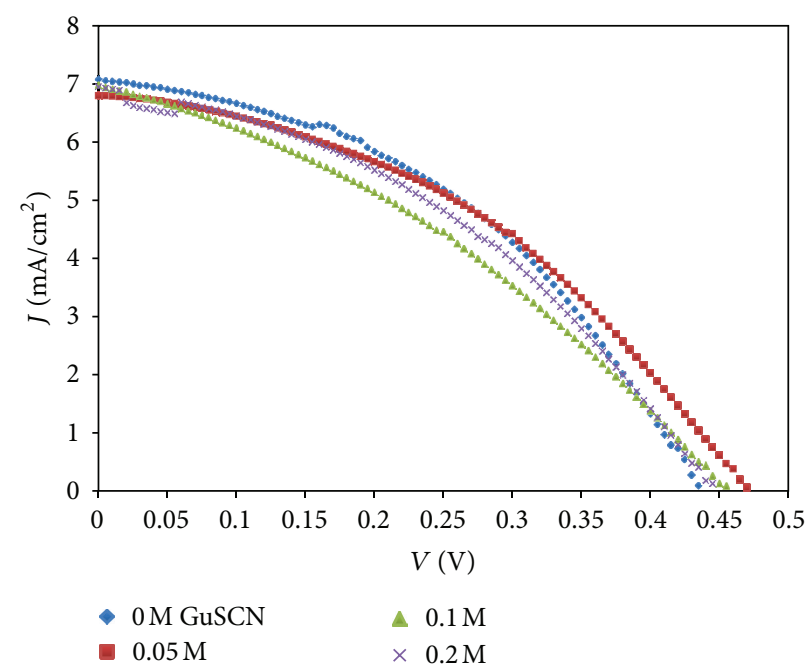

(a)

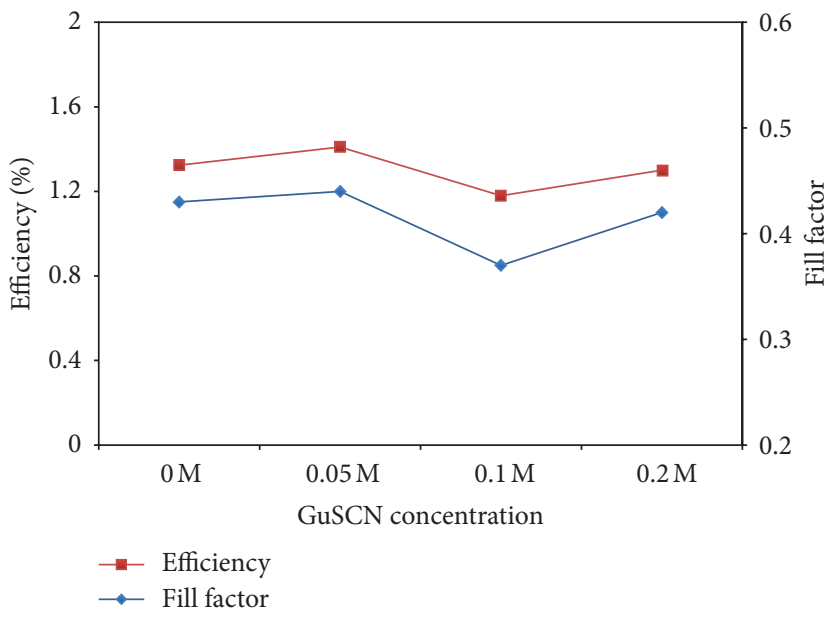

(b)

FIGURE 5: (a) $J-V$ curves of CdSe QDSSCs with electrolytes having various amounts of GuSCN additive. (b) Variation of efficiency and fill factor of the cells with the amount of GuSCN in the electrolyte. Electrolyte used: $0.5 \mathrm{M} \mathrm{Na}_{2} \mathrm{~S}, 0.1 \mathrm{M} \mathrm{S}$ in ethanol/water ( $8: 2$ by volume). 


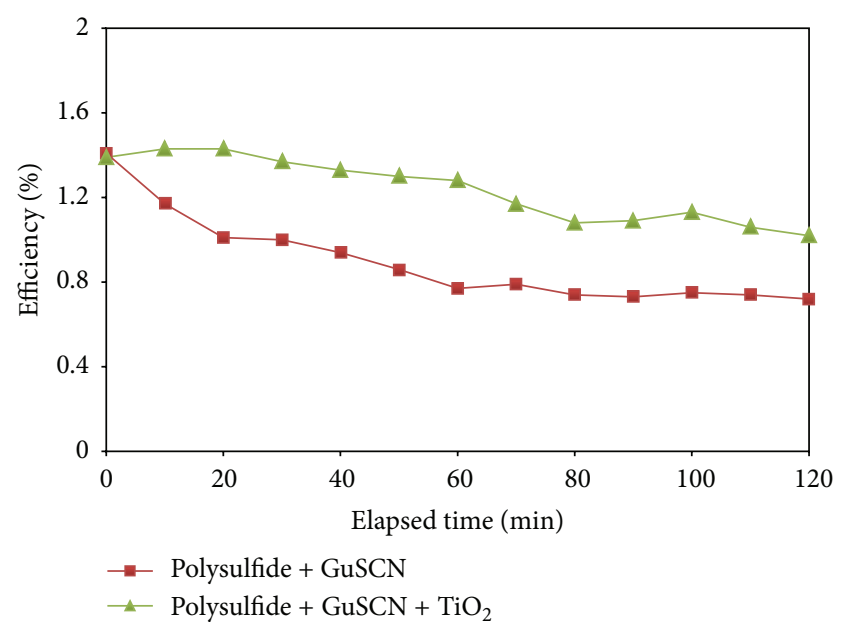

FIGURE 6: Efficiency variation of CdSe QDSSCs with time under two-hour light soaking. The polysulfide electrolytes used in the cells were with and without added $\mathrm{TiO}_{2}$ nanoparticles.

This translates to about $27 \%$ decrease from initial value. The decrease in performance is also noted, and this can be attributed to the decrease of photocurrent density and opencircuit voltage. With the addition of $\mathrm{TiO}_{2}$ to the electrolyte solution, stability of the cell has improved substantially presumably due to enhanced stability of the electrolyte. The efficiency variation of the two cells in the two-hour light soaking period is presented in Figure 6. The presence of $\mathrm{TiO}_{2}$ is thought to have adsorbed on the QD surface and thus passivating the QD surface states which in turn decrease the recombination electrons from the photoanode into the electrolyte [14]. Thus, an improved performance and better stability are achieved. Although the mechanism involved in the stability improvement of the cell due to addition of $\mathrm{TiO}_{2}$ in the polysulfide electrolyte needs further investigation to understand, this method seems noteworthy for improving the stability of the QDSSCS using polysulfide liquid electrolytes.

When a CdSe-sensitized photoanode is dipped in the optimized polysulfide electrolyte solutions, UV-vis spectra obtained for the CdSe-sensitized photoanode before and after dipping into the electrolyte do not show any deviation. The results obtained are shown in Figure 7 . There is no significant change of absorbance before and after dipping of the electrode. The CdSe-sensitized $\mathrm{TiO}_{2}$ film appears to be having the same colour of dark brown before and after dipping (see inset in Figure 7). This signifies that no major chemical reaction occurs in the CdSe-sensitized $\mathrm{TiO}_{2}$ film upon exposure to polysulfide electrolyte. These results emphasize that polysulfide electrolytes are a better choice for CdSe QDDSSCs as the electrolytes do not produce any serious deterioration of the QDs.

\section{Conclusions}

A suitable polysulfide electrolyte has been investigated for use in CdSe-based QDSSCs. The optimum cell performance was obtained with polysulfide electrolyte consisting of $0.5 \mathrm{M}$ $\mathrm{Na}_{2} \mathrm{~S}, 0.1 \mathrm{M} \mathrm{S}$, and $0.05 \mathrm{M} \mathrm{GuSCN}$ in ethanol/water $(8 / 2$

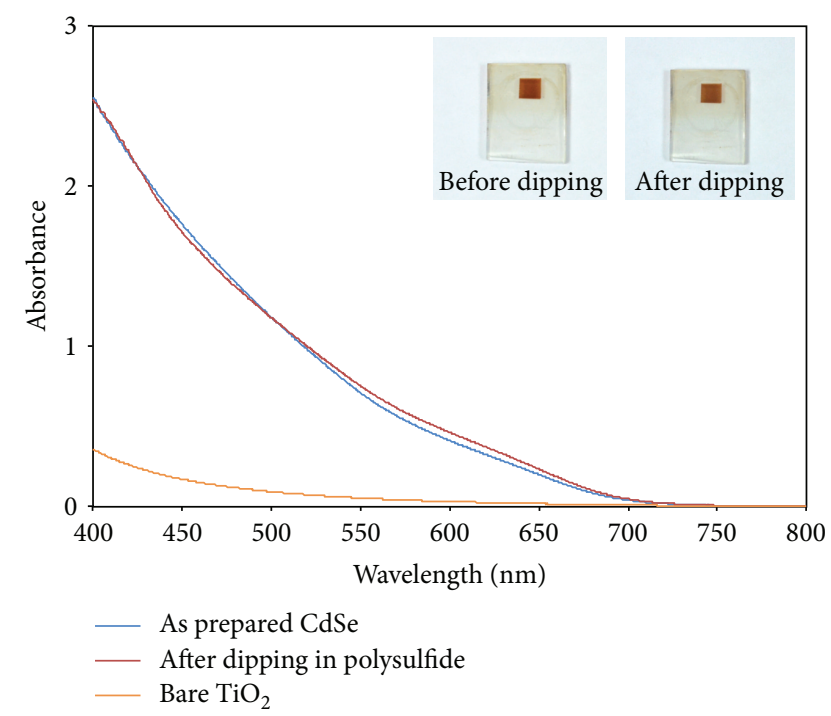

FIgURE 7: UV-vis spectra of CdSe-sensitized $\mathrm{TiO}_{2}$ electrodes before and after dipping in polysulfide electrolytes (inset: photograph of CdSe-sensitized electrodes before dipping and after dipping in polysulfide electrolyte).

by volume) solution. The CdSe QDSSC with this optimized polysulfide electrolyte has an efficiency of $1.41 \%$, a short circuit current density of $6.80 \mathrm{~mA} / \mathrm{cm}^{2}$, an open-circuit voltage of $0.47 \mathrm{~V}$ and a fill factor of $44 \%$. With the addition of $\mathrm{TiO}_{2}$ nanoparticles to the electrolyte, the stability of the cell is enhanced. A higher photocurrent density was also obtained with the inclusion of $\mathrm{TiO}_{2}$ nanoparticles. The polysulfide electrolyte has the potential to give good long-term stability for the CdSe QDSSCs as the QDs do not appear to undergo any serious deterioration.

\section{Acknowledgment}

The authors would like to thank University of Malaya for the IPPP Grant no. PV094-2012A. H. K. Jun thanks University of Malaya for a Fellowship Scheme scholarship award.

\section{References}

[1] B. O’Regan and M. Grätzel, "A low-cost, high-efficiency solar cell based on dye-sensitized colloidal $\mathrm{TiO}_{2}$ films," Nature, vol. 353, no. 6346, pp. 737-740, 1991.

[2] M. Grätzel, "Dye-sensitized solar cells," Journal of Photochemistry and Photobiology C, vol. 4, no. 2, pp. 145-153, 2003.

[3] R. Vogel, K. Pohl, and H. Weller, "Sensitization of highly porous, polycrystalline $\mathrm{TiO}_{2}$ electrodes by quantum sized CdS," Chemical Physics Letters, vol. 174, no. 3-4, pp. 241-246, 1990.

[4] R. Vogel, P. Hoyer, and H. Weller, "Quantum-sized PbS, CdS, $\mathrm{Ag}_{2} \mathrm{~S}, \mathrm{Sb}_{2} \mathrm{~S}_{3}$, and $\mathrm{Bi}_{2} \mathrm{~S}_{3}$ particles as sensitizers for various nanoporous wide-bandgap semiconductors," Journal of Physical Chemistry, vol. 98, no. 12, pp. 3183-3188, 1994.

[5] P. V. Kamat, "Quantum dot solar cells. Semiconductor nanocrystals as light harvesters," Journal of Physical Chemistry C, vol. 112, no. 48, pp. 18737-18753, 2008.

[6] W. W. Yu, L. H. Qu, W. Z. Guo, and X. G. Peng, "Experimental determination of the extinction coefficient of CdTe, CdSe, and 
CdS Nanocrystals," Chemistry of Materials, vol. 15, no. 14, pp. 2854-2860, 2003.

[7] V. González-Pedro, X. Xu, I. Mora-Seró, and J. Bisquert, "Modeling high-efficiency quantum dot sensitized solar cells," ACS Nano, vol. 4, no. 10, pp. 5783-5790, 2010.

[8] G. Zhu, L. Pan, T. Xu, and Z. Sun, "CdS/CdSe-cosensitized $\mathrm{TiO}_{2}$ photoanode for quantum-dot-sensitized solar cells by a microwave-assisted chemical bath deposition method," ACS Applied Materials and Interfaces, vol. 3, no. 8, pp. 3146-3151, 2011.

[9] A. J. Nozik, “Quantum dot solar cells," Physica E, vol. 14, no. 1-2, pp. 115-120, 2002.

[10] A. J. Nozik, M. C. Beard, J. M. Luther, M. Law, R. J. Ellingson, and J. C. Johnson, "Semiconductor quantum dots and quantum dot arrays and applications of multiple exciton generation to third-generation photovoltaic solar cells," Chemical Reviews, vol. 110, no. 11, pp. 6873-6890, 2010.

[11] Y. Chiba, A. Islam, Y. Watanabe, R. Komiya, N. Koide, and L. Han, "Dye-sensitized solar cells with conversion efficiency of 11.1\%," Japanese Journal of Applied Physics, vol. 45, no. 24-28, pp. L638-L640, 2006.

[12] M. Samadpour, A. Iraji zad, N. Taghavinia, and M. Molaei, “A new structure to increase the photostability of CdTe quantum dot sensitized solar cells," Journal of Physics D, vol. 44, no. 4, Article ID 045103, 2011.

[13] V. Jovanovski, V. Gonzalez-Pedro, S. Gimenez et al., "A sulfide/polysulfide-based ionic liquid electrolyte for quantum dot-sensitized solar cells," Journal of the American Chemical Society, vol. 133, no. 50, pp. 20156-20159, 2011.

[14] M. Shalom, S. Dor, S. Rühle, L. Grinis, and A. Zaban, "Core/CdS quantum dot/shell mesoporous solar cells with improved stability and efficiency using an amorphous $\mathrm{TiO}_{2}$ coating," Journal of Physical Chemistry C, vol. 113, no. 9, pp. 3895-3898, 2009.

[15] G. Hodes, "Comparison of dye- and semiconductor-sensitized porous nanocrystalline liquid junction solar cells," Journal of Physical Chemistry C, vol. 112, no. 46, pp. 17778-17787, 2008.

[16] Y.-L. Lee, B.-M. Huang, and H.-T. Chien, "Highly efficient CdSe-sensitized $\mathrm{TiO}_{2}$ photoelectrode for quantum-dotsensitized solar cell applications," Chemistry of Materials, vol. 20, no. 22, pp. 6903-6905, 2008.

[17] S. Rühle, M. Shalom, and A. Zaban, "Quantum-dot-sensitized solar cells," Chemical Physics and Physical Chemistry, vol. 11, no. 11, pp. 2290-2304, 2010.

[18] Y.- L. Lee and C.-H. Chang, "Efficient polysulfide electrolyte for CdS quantum dot-sensitized solar cells," Journal of Power Sources, vol. 185, no. 1, pp. 584-588, 2008.

[19] L. J. Diguna, Q. Shen, J. Kobayashi, and T. Toyoda, "High efficiency of CdSe quantum-dot-sensitized $\mathrm{TiO}_{2}$ inverse opal solar cells," Applied Physics Letters, vol. 91, no. 2, Article ID 023116, 2007.

[20] S. Giménez, I. Mora-Seró, L. Macor et al., "Improving the performance of colloidal quantum-dot-sensitized solar cells," Nanotechnology, vol. 20, no. 29, Article ID 295204, pp. 42084214, 2009.

[21] A. Salant, M. Shalom, I. Hod, A. Faust, A. Zaban, and U. Banin, "Quantum dot sensitized solar cells with improved efficiency prepared using electrophoretic deposition," ACS Nano, vol. 4, no. 10, pp. 5962-5968, 2010.

[22] Y. Tachibana, K. Umekita, Y. Otsuka, and S. Kuwabata, "Performance improvement of CdS quantum dots sensitized $\mathrm{TiO}_{2}$ solar cells by introducing a dense $\mathrm{TiO}_{2}$ blocking layer," Journal of Physics D, vol. 41, no. 10, Article ID 102002, 2008.
[23] H. Lee, M. Wang, P. Chen et al., "Efficient CdSe quantum dotsensitized solar cells prepared by an improved successive ionic layer adsorption and reaction process," Nano Letters, vol. 9, no. 12, pp. 4221-4227, 2009.

[24] G. Vázquez, E. Alvarez, and J. M. Navaza, "Surface tension of alcohol + water from 20 to $50^{\circ} \mathrm{C}$," Journal of Chemical and Engineering Data, vol. 40, no. 3, pp. 611-614, 1995.

[25] R. Costi, A. E. Saunders, E. Elmalem, A. Salant, and U. Banin, "Visible light-induced charge retention and photocatalysis with hybrid CdSe-Au nanodumbbells," Nano Letters, vol. 8, no. 2, pp. 637-641, 2008.

[26] I. Mora-Seró and J. Bisquert, "Breakthroughs in the development of semiconductor-sensitized solar cells," Journal of Physical Chemistry Letters, vol. 1, no. 20, pp. 3046-3052, 2010.

[27] B. R. Müller, S. Majoni, D. Meissner, and R. Memming, "Photocatalytic oxidation of ethanol on micrometer-and nanometersized semiconductor particles," Journal of Photochemistry and Photobiology A, vol. 151, no. 1-3, pp. 253-265, 2002.

[28] Z. Yang, C.-Y. Chen, P. Roy, and H.-T. Chang, "Quantum dotsensitized solar cells incorporating nanomaterials," Chemical Communications, vol. 47, no. 34, pp. 9561-9571, 2011.

[29] S. Licht, "A description of energy conversion in photoelectrochemical solar cells," Nature, vol. 330, no. 6144, pp. 148-151, 1987.

[30] N. Ardoin and J. Winnick, "Polysulfide solution chemistry at a CdSe photoanode," Journal of the Electrochemical Society, vol. 135, no. 7, pp. 1719-1722, 1988.

[31] C.-Y. Chou, C.-P. Lee, R. Vittal, and K.-C. Ho, "Efficient quantum dot-sensitized solar cell with polystyrene-modified $\mathrm{TiO}_{2}$ photoanode and with guanidine thiocyanate in its polysulfide electrolyte," Journal of Power Sources, vol. 196, no. 15, pp. 65956602, 2011.

[32] C. Zhang, Y. Huang, Z. Huo, S. Chen, and S. Dai, "Photoelectrochemical effects of guanidinium thiocyanate on dyesensitized solar cell performance and stability," Journal of Physical Chemistry C, vol. 113, no. 52, pp. 21779-21783, 2009.

[33] S. K. Sarkar, N. Chandrasekharan, S. Gorer, and G. Hodes, "Reversible adsorption-enhanced quantum confinement in semiconductor quantum dots," Applied Physics Letters, vol. 81, no. 26, pp. 5045-5047, 2002.

[34] T. Zewdu, J. N. Clifford, J. P. Hernandez, and E. Palomares, "Photo-induced charge transfer dynamics in efficient $\mathrm{TiO}_{2} / \mathrm{CdS} / \mathrm{CdSe}$ sensitized solar cells," Energy and Environmental Science, vol. 4, no. 11, pp. 4633-4638, 2011.

[35] M. A. Hossain, J. R. Jennings, C. Shen et al., "CdSe-sensitized mesoscopic $\mathrm{TiO}_{2}$ solar cells exhibiting $>5 \%$ efficiency: redundancy of CdS buffer layer," Journal of Materials Chemistry, vol. 22, no. 32, pp. 16235-16242, 2012.

[36] H. J. Lee, J. Bang, J. Park, S. Kim, and S.-M. Park, "Multilayered semiconductor (CdS/CdSe/ZnS)-sensitized $\mathrm{TiO}_{2}$ mesoporous solar cells: all prepared by successive ionic layer adsorption and reaction processes," Chemistry of Materials, vol. 22, no. 19, pp. 5636-5643, 2010.

[37] P. V. Kamat, "Boosting the efficiency of quantum dot sensitized solar cells through modulation of interfacial charge transfer," Accounts of Chemical Research, vol. 45, no. 11, pp. 1906-1915, 2012. 

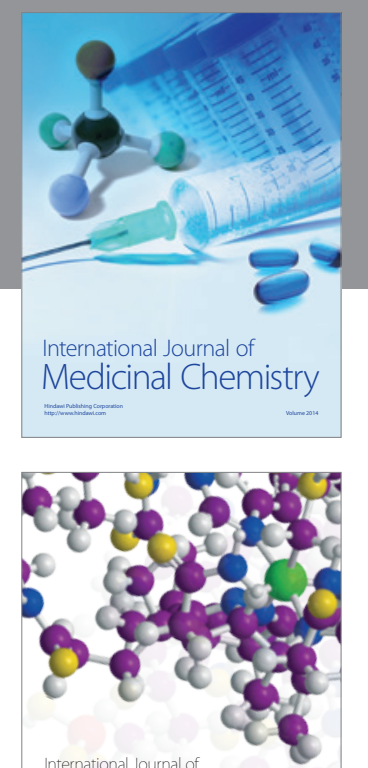

\section{Carbohydrate} Chemistry

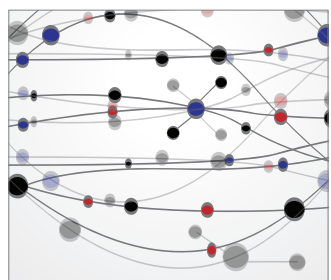

The Scientific World Journal
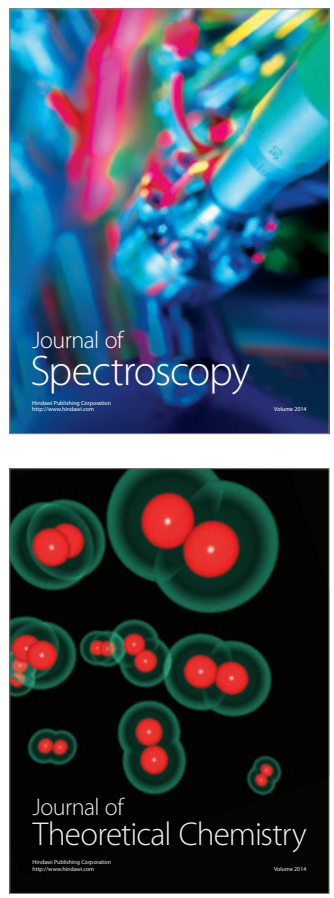
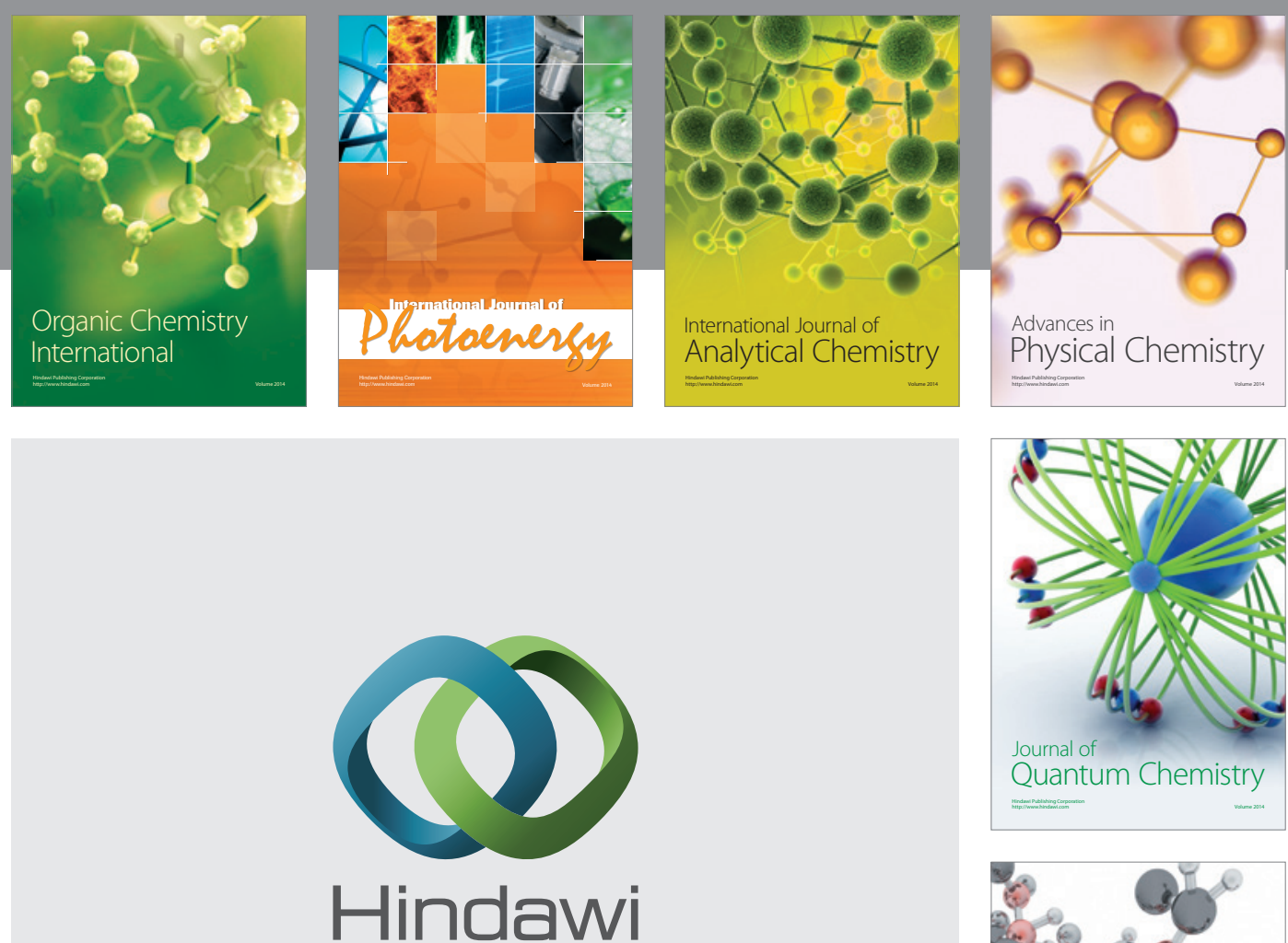

Submit your manuscripts at

http://www.hindawi.com

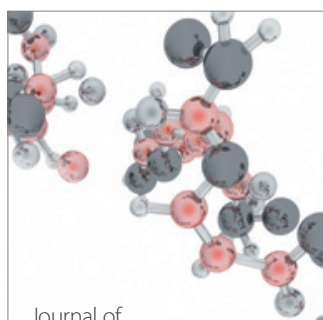

Analytical Methods

in Chemistry

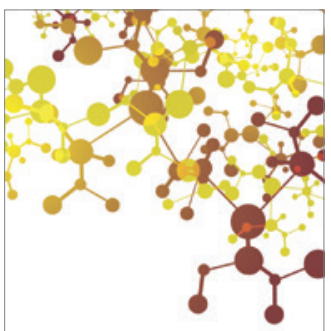

Journal of

Applied Chemistry

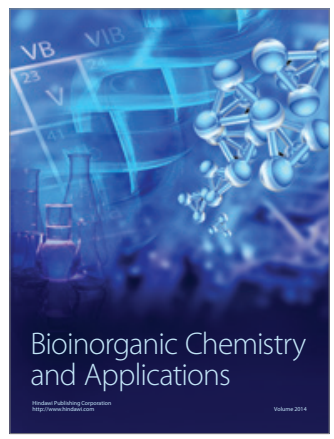

Inorganic Chemistry
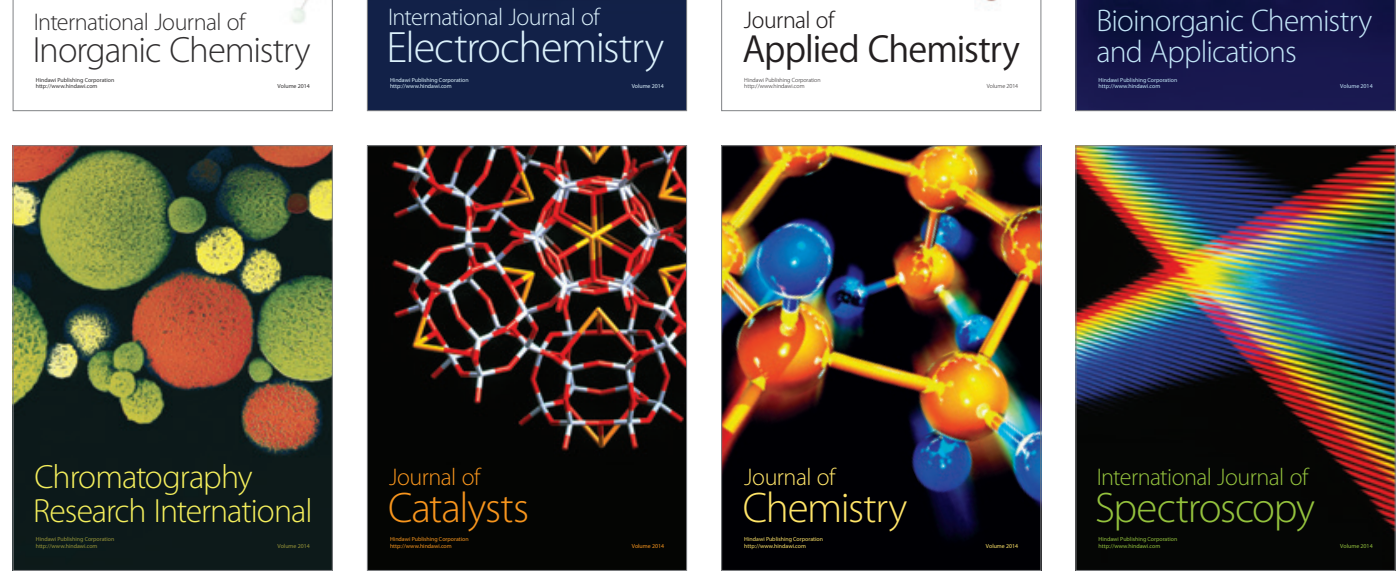